\title{
국제개발협력의 변화와 추세 ${ }^{1)}$
}

\author{
이 계 우/서울대 국제대학원 초빙교수
}

\section{[ Abstract ]}

Since 2007, the government of Korea has been taking steps to become a member of the Development Assistance Committee of the OECD. The government has also been increasing the amount of its official development assistance and is planning on raising it further in the next five years. In the face of these changes, it is timely to look into the prospects and challenges of the Korean ODA as a member of the DAC.

This paper aims to help modernize the intemational cooperation of the government of Korea by reviewing the origins and evolution of advanced countries' ODA to date, highlighting the main trend of the international development cooperation of DAC member states in recent decades, and drawing some lessons and insights from the review.

\section{I. 머리말}

우리나라는 세계적 으로 생산과 교역의 선두주자 그룹 에 진입하였고 $\mathrm{OECD}$ 의 회원국이 된지도 10 년이 넘 었다. 이제 선진국 그룹의 일원으로서 $L$ 역할과 칙임 을 다하기 위하여 선진원조국으로 구성된 $\mathrm{OECD}$ 의 국 제개반원조위원 회(Development Assistance Committee: DAC)에 2010년에 가입하기 위하여 심사
절차를 밟고 있다. 이 위원회의 회원으루서 임무를 수 행하기 위해서는 먼지 선진 원조공여국들은 어떠한 원 조정책을 수립하였고 또 실제로 어떻게 그 정책을 운 영해 왔는가를 살펴보는 것은 우러나라의 국제개발협 력의 신진화를 도모하는데 중요한 이정표가 될 것이 다. 본 논문은 이러한 목적에서 국제기발협력의 기원 과 그 변화의 과정을 살펴보고, 또 최는의 추세를 특징 사우려ㄱㅗㅗ 한다. 
여기에서 말하는 국제기발협력 (international development cooperation) 또는 공적개발원조 (Official Development Assistance: ODA)는 다음과 깉은 특징을 가진다. 첫째, 공여주체가 징부 및 공공기 관이라는 점에서 민간기업이나 딘체의 원조와 구별된 다. 둘째, 공여의 대상이 DAC가 개발도상국이라고 정 한 중소득 이하의 국가나 국제기구라야 한다. 느 외의 원조는 단순히 공적원조이지 공적 개발원조가 아니다. 셋째, 공여의 목적이 개발 즉 경제사회개발과 복지증 진이라야 한다. 이런 의미에서 공적기발원조는 군사적 원조, 종교적 원조, 학술문화적 원조 등 비경 제적 원조 와 다르녀 또 공적 수출신용이나 투자금응 등 기타 경 제적 원조와도 구별된다. 넷째, 공여조건이 양허적 (concessional) 이라야 한다는 점에서 국제자본시장의 상업적 대출이나 채권이나 유가증권의 발행과도 구벌 된다. 양허율은 국제자본시장의 상업적 조건과 비교하 여 $25 \%$ 이상이어야 한다. 이러한 공적개발원조(ODA) 는 다양한 형태를 취한다. 즉 기술 뚜는 투자프로젝트 원조이거나, 분야별(sector) 원조이거나, 프로그램 원 조(예산, 국제수시, 수입시원 등)이거나, 식량시원 등 긴급재난구호나 채무탕감 등을 포함한다.

\section{II. 국제개발협력의 기원과 변화}

공적개발원조 $(\mathrm{ODA})$ 는 공여주체가 국제기구인가, 아 니면 기별 국가인가에 따라서 다자간 ODA와 양자간 ODA로 구별된다. 다자간 ODA는 1945년에 세워진 $\operatorname{IBRD}$ (궂제부흥개발은행)에 일반적으로 그 기원을 두 고 있다. 이에 비하여, 양자간 ODA는 1948 51년 사
이에 미국이 유럽의 17 게 국의 경제회복을 위하여 $\$ 16.4$ 십억을 제공한 마샬계획(Marshall Plan)에 그 기원을 다고 있다 (Yoo and Lee 2002), 마샬계힉은 한편으로는 미국의 인도주의에 바탕을 두고 있지만, 다른 한편으로는 소련을 중심으로 하는 공산주의체제 에 대처할 수 있는 민주체제와 시장경제를 구축하기 위하여 이에 필요한 경제환경 특히 사회간접자본의 회복을 목적으로 했다. 나샬플랜에 의한 원조를 호율 적으로 횔용하기 위하여 유럽국가들은 1948년에 OFFC(Organization of Furopean Fconomic Cooperation)나는 국제기구를 만들어서 수혜국간의 원조사용:계획과 조정을 도모하였다.

이렇게 2 차 세계대전 후 유럽 국가와 일본의 경제재건 과 냉전체제에 목적을 둔 1950 년 대의 양자간 원조는 유럽국가가 경제환경을 회복함에 따라서 1960 년 대 부터는 개발도상국을 주된 원조대상으로 삼고, $\mathrm{OEEC}$ 를 OECD(Oryanization of Economic Cooperation and Development)라는 개발기구로 획대 재꾸성하였 다. 이 기구는 선진국간의 경제정책의 조정과 함께 개 도국의 경제사회 발전을 향상시키는 것을 목적으로 시 직하였다. $\mathrm{OECD}$ 의 회원국은 경제규모를 획대하고 지 속적으로 성장하기 위하여서는 생산에 필요한 원자재 의 시속적인 공급과 제품의 소비시장을 확대할 필요가 있었고 이러한 필요성을 개도구에서 충족할 수 있었 다. 특히 개도국에 대한 원조를 효율적으로 제공하고 활용하기 위하여 $\mathrm{OFCD}$ 는 1961년에 원조공여국들 간 의 조정을 목적으로 하는 $\mathrm{DAC}$ 를 구성하여 운영하여왔 다. DAC 회원국들의 원조는 자신들의 경제회복경험을 바탕으로 하여 개도국의 인프라개빌에 중짐을 둔 것이 
었다. 또 1960 년대 말에 유엔과 국제게발금융기구체 제하에서 선진국은 피어슨 보고서(Pearson Report)를 채택함으로써 각 국의 GDP의 $0.7 \%$ 까시 원조규모를 획대하기로 합의하였다.

그러나 1970 년대에 들어와서 두 차례에 걸친 석유값 인상파동을 거치면서 개도국은 선진국과 비교하여 교 여조건의 아화를 겪게 되고, 국제적으로는 물론 국내 적으로 심각한 빈부격차를 노출하게 되었다. 선진국이 제공한 인프라 중심의 원조는 이러한 빈곤문제를 단기 간에 해결하시 못하었을 뼌만 아니라 이미 건설된 인 프라도 인럭과 기술 및 제도의 결핍으로 유지되기도 어려웠다. 따라서 세계은행과 기타 국제개빌금응기구 가 중심이 되어서 기도국에 대한 원조는 시회간접자본 위주의 원조에서 기본적 인 인간다운 생활(Basic Hum an Noeds)을 보장하는 것에 우선을 둔 빈곤퇴치 원조로 초짐을 이전하게 되있다. 따라서 식량의 증산 을 위한 농촌개발과 기본적인 생횔수준을 획보하기 위 한 교-육, 보건, 기술훈련 등 사회개발로 원조의 초점이 옮겨갔다.

1980년대에 들이와서 국제개발협력에 관한 환경이 많 이 달라졌다. 빈곤퇴치를 위한 원조가 격감하게 된 것 이다. 대부분의 개발도상국가들은 급격한 왜채부담의 증가에 허덕이게 되었다. 국제기구는 개도국의 채무불 이행사태를 예방하고 완화하기 위하여 대규모의 구조 조정차관과 왜채탕감원조를 제공하는데 주력하였고, 양자간 원조도 이러한 국제가구의 원조에 헙조하거나 독립적으로 외채탕감에 주럭하였다. 그러나 선진국은 식유파동의 영향을 어느 징도 흡수하였으나 경제적 불
황을 걲게 되면서 원조의 규모를 삭감하게 되어 빈곤 퇴치를 위한 원조재원이 고갈되게 되었다. 따라서 개 도국은 외채누적과 경기침체, 정치불안, 만성적 빈곤 에 빠지게 되었다.

\section{III. 최근 국제개발협력의 추세}

1990년대 이 후의 국제개발협력은 다음과 같은 특징 을 가진다고 할 수 있다.

\section{1. 빈곤퇴치와 개발협력}

동독의 붕괴와 소비에트 사회주의 언방공화국(USSR) 의 해체로 시작되는 1990 년대에 들어와서 냉전의 종 시과 함께 공적개발원조가 격감하고 경제자유화로 내 표되는 세계화의 추세가 빠르게 진전됨에 따라, 전 세 계적 으로 국가 간은 물론 국가 내에서 빈부의 격차는 더욱 커지고 번런인구는 증가해았다. 더욱이 냉전의 종식은 많은 개도국과 체제전환경제(transitional economies)내에서 지역적, 종족적, 종교적 분쟁을 야 기시키게 되었고 그 결과 빈곤인구가 속출하였다. 2000 년대에 들어와서 세계인구의 $18 \%$ 에 달하는 11 억 의 인구가 하루에 1 달더 미만의 소득으로 생할하는 절 내빈곤에 처하게 되었다. 이러한 현상은 득히 저소득 층 국가에서 더욱 극명하게 나타났다. 그러나 원조규 모는 걱감하였다. 양자간 원조의 대종을 이루었던 미 국의 예를 들면, 1970-80년대에 GNP의 0.35\%를 원 조로 제공하였으나 1990 년 중반에 들어서는 $0.23 \%$ 의 원조만 제공하였다. 그나마 제공된 원조는 주로 구 동 
구권 및 중앙아시아 국가들의 경제체제전환(economic transition)을 위하여 제공되었고 또 아시아, 러시아 및 남미 지역의 경제위기를 해결하기위한 긴급사금시 원에 활용되어서 대다수의 개발도상국의 심각한 빈곤 문제를 외면하였다.

이러한 현상에 대처하기 위하여 세계 각국은 국제개발 협럭의 목표를 다시금 빈곤퇴치에 두어야 한다는 정책 을 추구하게 되었다. 1995년 스웨덴의 수도 스톡홀름 에서 기최된 사회기발정상회의(Social Development Summit)에서 빈곤문제의 심각성이 제기된 이후, 선 진국들이 개발협럭을 목적으로 창설한 $\mathrm{OECD}$ 의 $\mathrm{DAC}$ 는 1996년 5월에 21세기를 위한 새로운 개빌전략 (Shaping the 21st Century: The Contribution of Development Cooperation)을 채택하여, 2015년까지 빈곤층을 절반으로 줄인다는 국제개발목표 (International Development Gcals: IDGs)를 공표하
였다. 이리한목표는 2000 년 9 월에 세계 189 기국의 정 상들이 참석한 $\mathrm{UN}$ 의 새천년 정상회의(Millennium Summit)에서 새천년 개발목표 (Millennium Development Goals: MDGs)라는 8개 항에 딜하는 새 로-운 목표로 재친명되었다. 구체적으로 MDG는 전대 빈긴퇴치, 보편적 초등교육달성, 양성평등과 여성지위 향상, 모사보건확대, 영아 및 아동사망율 감소, 전혐병 퇴치, 상하수도 위생시설 보급과 환경보호, 글로벌 파 트너쉽이라는 8 개 목적에 관한 구체적 목표를 선정하 여 2015 년 까지 달성할 것을 내용으로 하였다.

\section{2. 공적개발원조 개념의 확대}

빈곤문제의 해결에 무력한 공적기발원조를 게혁하기 위하여 $\mathrm{OECD} / \mathrm{DAC}$ 는 일련의 정직을 제시하였다. 즉 개발과 안보를 통합하기 위한 공적개발원조(ODA)개념 의 확대; 무역, 투자, 개발징책 등 붱개도국 정책간의

(표 1) 새천년 개발목표 (MDG)

\begin{tabular}{|c|c|}
\hline 믁 적 & 목 \\
\hline \multirow{2}{*}{ 극빈과 기아 근절 } & 목표 : 1일 소득 달러 이하 인구반감 (1990년-20 5년) \\
\hline & 목표 2: 기이로 고동 받는 인구를 반감 (1990년-2015년) \\
\hline 2. 보편적 기초교육달성 & 목표 3: 2015년까지 전국의 소년 소녀 구분 없이 모든 기초 교육과점을 끝낼 수 있게 보장 \\
\hline 3, 양섬평등 및 여성정책 & 목표 4: 가능한 2005년까지 기초 및 중등교육과정에서, 20-5년 까지는 모든 교육과정에서 성적 불평등 제거 \\
\hline 4. 아동 사망률 축소 & 목표 5: 1990에서 2015년까지 5세 이하의 사망률을2/3 줄이기 \\
\hline 5. 모섬건감증진 & 목표 6: 1990년에서 2015년까지 모섬 사맘률(MMR)을 3/4 감소시키기; 전 산모의 의료시설 접근 가능하게하기 \\
\hline $\begin{array}{l}\text { 6. HN/AIDS, 말라리아듬, } \\
\text { 질병과의 전잠 }\end{array}$ & 목표 7: HN/AIDS의 전염을 2015년까지 현상유지 나지 감소시키기 시작하기 \\
\hline 7. 지속가능한 환경확보 & $\begin{array}{l}\text { 목표 8: 상하수도와 위상시설 미접근 인구 반감; 2020년까지 백만 도시빈민 생활수준 향상, 지속가늠한 발전을 } \\
\text { 국가점책에 반염; 환겸자원유실 반전 }\end{array}$ \\
\hline $\begin{array}{l}\text { 8. 지구 적 개발파트 너쉽 } \\
\text { 구축 }\end{array}$ & 목표 9: 자유무역-금융제도 개발,무역-금융 원조에서 최빈국 특벌 고려: 개도국에 신기술과 기본약품 접근기회 부며 \\
\hline
\end{tabular}


일관성 유지: 국벌 지원의 선별성(selectivity)강화: 기 도국의 국가발전정칙과의 일치(alignment); 원조의 질 향상과 효과성 증대; 원조 이행점검과 성과측정; 대안 적 재원조달 방안 등을 논의해왔다. 최근 안보와 분쟁 예방이 개발원조의 주요 이슈로 논의됨에 따라 ODA의 개념을 확대하여 안보지원 활동을 공적 개발원조통-계 에 포함시키자는 주장이 제기되었다. 또한 2004년 $\mathrm{DAC}$ 고위급회의에서는 아래 8가지 항목을 공적 개발 원조에 포함시키기로 합의하였는데 예를 들면, 민주적 거버년스와 안보체계에 대한 문민통제를 향상시키는 능력 배양, 안보체제 검토, 안보관련 지출관리, 안보체 제에 내한 시민사회 옇할 강화, 소년병사해체, 신뢰구 추과 분쟁예방 조치, 소형 무기와 경무기 확산 방지를
위한 원조 등이다. 특히 일본은 2002년에 제정 된 국제 개발협력헌장에 인간안보(human security)라는 개념 을 정립하여 국제개발협력의 중요한 목적으로 삼았다 (Sunaga 2004, Inada 2005).

\section{3. 공적개발원조의 양적확대}

$\mathrm{MDG}$ 를 달성하기 위한 국제사회의 공동노럭은 2002년 에 멕시코 몬테레이에서 개발재원회의(Development Finance Conference)를 기최하고 선진국이 당시 GNI 대비 $0.25 \%$ 수준에 있는 ODA를 2009년까시 $0.5 \%$ 로, 또 2015 년까지 $0.7 \%$ 로 확대할 것을 결의하였다. 최근 에는 $\mathrm{MDG}$ 달성 중간점검을 위해 개최된 2005년 9월

〈그림 1) 순 ODA의 국제적 현황(2007) 과 추정(2008 2010)

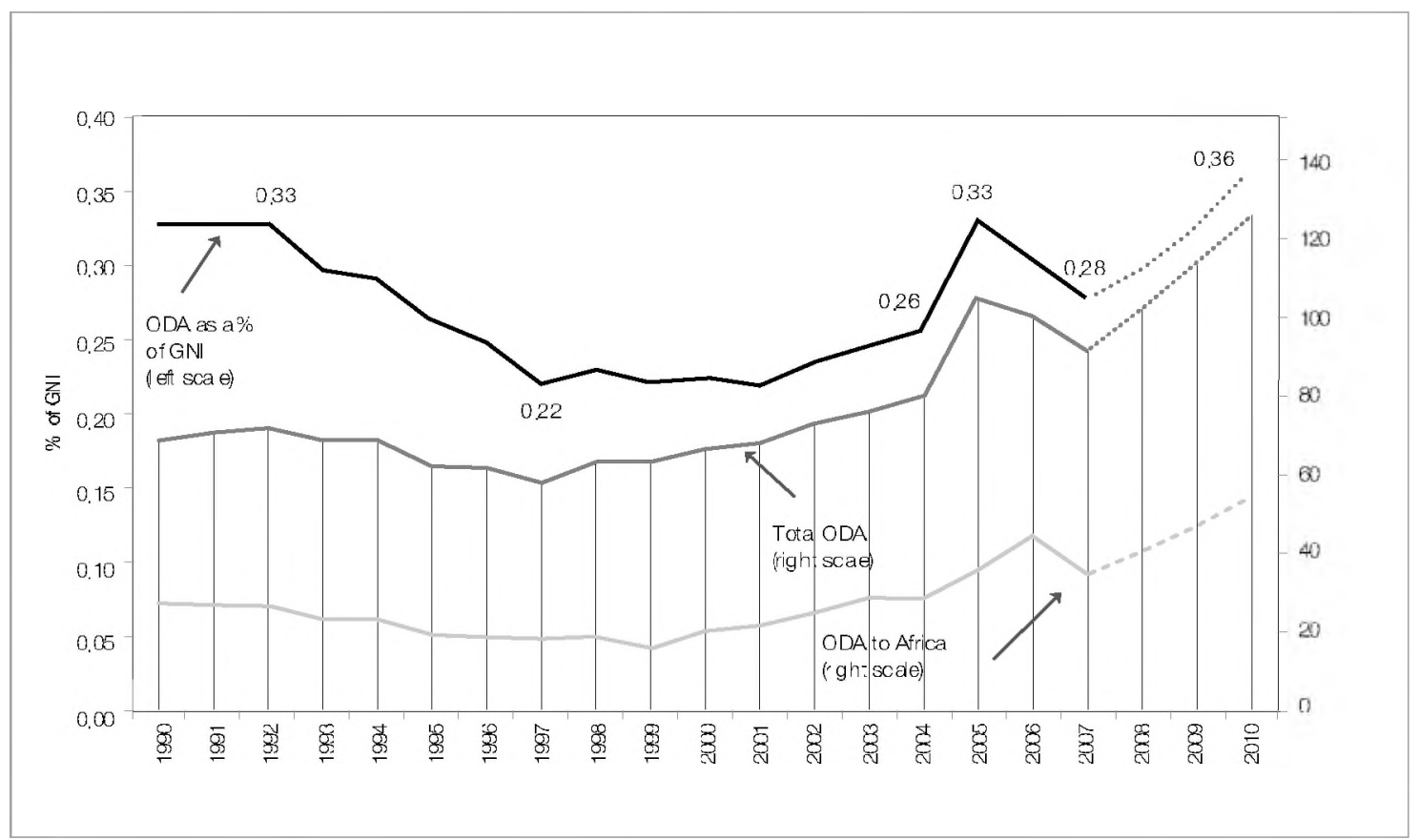

$\therefore$ 자류: $\mathrm{DAC}(2008)$ 
의 제60차 UN 정상회의에서 $\mathrm{ODA}$ 확대요구가 재확인 되었고, $\mathrm{ODA}$ 중 최빈국 원조가 차지하는 비율을 2010 년까시 GNI의 $0.15 \% \sim 0.20 \%$ 로 확대하기로 하였다. 호주와 뉴질랜드는 독자적으로 원조증대 일정을 제시 하였고, 미국, 캐나다, 인본은 공여액 중심의 목표를 설 정하었다. 따라서 ODA의 규모는 2004년 현재 80십억 달더정도에서 2010 년에는 130 십억 달러에 달하며 $\mathrm{GNI}$ 의 $0.36 \%$ 에 달할 것으로 $\mathrm{DAC}$ 는 전망했다.

선진국들은 이러한 합의의 중간점점을 2007년에 하기 로 하였다. 2005-2006년 사이에 원조는 확실히 증가 하여 2006년에는 2005년에 이어서 원조액이 $\$ 100$ 십 익을 초과하였고( $\$ 104.4$ 십읙), DAC의 2006년 목표인 GNI대비 원조액 $0.33 \%$ 를 이미 2005년에 달성하였다. 이는 2004 년에 비하여 $0.07 \%$ 포인트 증가한 것을 의 니한다. 오직 이태리, 그리스, 스페인, 포르투갈 등 최 근에 $\mathrm{DAC}$ 에 가입한 국가만 목표를 달성하지 못하였 다. 2006 년의 원조는 GNI 대비 $0.31 \%$ 를 기곡하었다.

- 느너나 2006년의 총 원조규모의 증가는 내실있는 증가 를 의미하지 읺는다. 왜냐하면 2006년의 총 원조액의 $1 / 5$ 에 해당하는 $\$ 19$ 백만이 개도국, 특히 이라크와 나이 지리아에 대한 부채탕감액이기 때문이다. 실제로 게도 국이 사용할 수 있는 원조액은 오히러 $0.8 \%$ 감소하었 다. 2007년에도 총원조액은 $\$ 100$ 십억을 능가하였으나 (\$103.5십억), 2006 년에 비하여 감소해서 $\mathrm{GNI}$ 대비율 도 $0.28 \%$ 로 줄었다. 다만 부채탕감액이 2006 년의 절 반으로 감소하였기 때문에 실제로 사용가능한 원조액
은 2006년에 비하여 $2 \%$ 증가하였다.

\section{4. 원조효과성의 제고}

원즈의 양이 확대됨에 따라 원조의 진, 특히 원즈의 효 과성 제고방안에 관한 논의가 국제원조의 중심과제로 대두되게 되었다. 느 배경에는 원조의 질적 개선을 통 하여 원조의 효과가 확대되지 않으면, 선진국이 구민들 을 선득하여 원조의 양적확대를 지속하기 어렵다는 인 식이 팽배해 있기 때문이다. 또 원조의 양이 증가함에 따라서 원조가 비효율적으로 낭비될 가능성이 더 크다 는 우려가 있기 때문이다. 사실 원조의호과 득히, 원조 가 경제성장에 미치는 효과가 있있는가에 관한 연구는 논쟁의 끝을 보지 못하고 여러 상반된 주장이 계속되고 있다. 이러한 주장은 대체로 다음의 네 가지 주류로 분 류할 수 있다 (이계우 2007).

첫째, 원즈는 경제성장에 이떠한 보탬도 되지 못하고 오히려 성장을 저해하는 효과를 가지고 있다는 주장이 다. 이러한 주장은 1970년대부터 주로 Freedman, Bauer, Easterly, Rajan and Subramanian 등의 연구 갈들에 의하여 최근까지 주장되고 있다.

둘째, 일반적으로 원조는 경제성장에 적극적인 영향을 미치지만, 수의체감(diminishing returns)을 보인다는 것이다. 이러한 주장은 주로 1990 년대에 IMF의 연구 가들(Dalgaard, Hansen, Tarp)에 의하여 주장되어왔 는데, 원조가 많을수록 경제성장은 키가지만 원조의 규

2) 이들의 언구에 의하면, 원조는 관료조직을 확대하고, 엘리트 계층을 더욱 부유히게 하고, 부패한 정권을 유지시키며, 소위 네델란드 벙을 키우며, 농산물가 격을 하락시킴으로씨 놈민소득을 감소시킨다 고 주장한다 
모가 기짐에 따라 원조가 성장에 미치는 영향은 점차 줄어든다는 것을 발견 했다

셋째, 원조는 일반적으로 경제성장에 적극적인 영향을 미치는 것이 아니고, 오직 공여국과 수혜국의 특정한 조건하에서만 적극적인 영향을 미친다는 연구결과이 다. 먼서 수원국이 특정한 조건을 충족시킬 때에 원조 가 경제성장에 적극적인 영향을 비친다는 것이다. 이 러한 주장은 주로 세계은행의 연구가들에 의하여 주장 되어 왔는바, 수원국의 국민들이 시민자유권을 많이 향유하고 있을 때에만 세계은행이 제공하는 원조가 효 과적이었다는 것을 발견했다 (Jonathan Isham, Daniel Kaufmann, Lant Pritchett). 또 Burnside와 Dollar (2000)는 수원국이 올바른 거시경제 정책이나 제도를 구비하고 있을 때에만 원조가 경제성장에 효과 적이었다는 것을 발견했다. 이러한 주장은 원조공여국 의 경험과도 일치하는 바가 크기 때문에 일반적으로 수용되고 있고, 국제원조기구나 선진 원조공여국은 이 러한 발견을 실제 원조사업에 반영하려고 하고 있다. 예를 들면, 미국의 비시 행정부가 2001년에 새천년도 전계좌(Millennium Challenge Account)라는 새로운 원조칭구를 개선하고 최빈국이 일정한 조긴을 충족할 때에만 무상원조를 계속하여 제공하는 것을 원칙으로 하고 있다"
넷째, 가장 최근의 방대한 경험적 연구에 의하면, 원조 의 경제성장효과는 원조의 중류에 따라서 다르다는 발 견이다 (Clemens, Radelet, Bhavnani 2004), (i) 식량 제공과 같은 재난구조나 인도주의적 원조는 경제성장 에 빈대의 효과를 가져 오는 것을 발견헸다. (ii) 교-육, 보건, 환경 과 같이 장기간에 걸쳐서 간접적으로 그 효 과가 나타나는 원조는 경제성장에 긍정적이시만 미약 한 호과를 가져왔다. (iii) 도로, 관개, 발전, 항만 등 사 회간접자본 등 단기간에 경제횔동에 직접적으로 기여 하는 원조는 경제성장에 강력한 긍적적 호과를 가져왔 다. 다만 1 효과가 체감적으로 나타났다

공적원조의 양적확대와 병행해서 선진국은 원조의 효 과성을 제고하기 위한 노력을 겅주해야 한다는데 의견 을 모아왔다. 2005년 2월 DAC의 파리고위급 포럼에 서 원조의 호과성 향상을 위한 파리선언이 채택되었고 (Paris Declaration on Aid Effectiveness), 이를 실행 에 옮기기 위하여, 12 가지의 지표를 선정하고 이를 달 성하기 위한 세부 목표와 평가방법에 합의했다. 파리 선언의 핵심은 첫째, 개발도상국은 주인의식 (Ow nership)을 가지고 자체적인 빈곤퇴치개발전략 (Poverty Reduction Strategies)을 수립하여야 한다. 둘째, 선진국은 기도국의 기발전략과 일치하는 원조를 제공해야한다(Alignment). 셋째, 원조공여국들 간에

\footnotetext{
3)이에 반하여, 원조의 효과는 공여국의 원조의 질에 의존한다는 주장도 강하다. 유삼뭔조(cans and cedts)가 무상공여 (grants) 보다 더욱 효뮬적이머, 다자 간 원조가 양자간 원조보다 더 효율적이고, ㄱㄱㄱ적 비연계성 (untied) 원조가 국적 인계성 (fied) 원조보다 더 효율적이라 고 주장한다 . 또 방대한 조직을 가진 원 조기관과 보고의무를 과도하게 부담하거 하는 원조기관의 원조나 감독과 평가를 검시하는 원조기관의 원조는 비효과적이 며, 수원국에거 주인의식을 심어 주고 원조의 우선순위와 프로그램의 내용에 관하여 광범위한 참가기회왕 결정권을 부여하는 원조기관의 원조는 경제성장에 더 효과적이라는 주장이다. 이러한 주장은 $\mathrm{DAC}$ 회뭔국시이에서 흔히 주장되지만, 경힘적 면구들 돟히여 체계적으로 뒷받짐되지 는 못 히였다.

4 이러한 직접적민 원소기 $1 \%$ 포민트 증기함에 따라 경제성장은 4 년간에 걸쳐서 년 평균 $0.3 \%$ 포인트 상승히였다. $\$ 1$ 의 직접적 원소를 제공히면 수원국 소득이 $\$ 1.0$ 증가하는 셈이다. 원조의 효과가 체감하기 때문에 현재 각국이 제공하는 직점적 원조의 폄균 3 배에 해당하는 수준에서 원조의 효과가 극대화 되고 그 이후에는 효과가 감소되는 것으로 조시되었다. 따라서 인프라 긴설을 위한 직접적 원조가 증대되면 경제성장의 효과도 커진다는 결론이다. 또 이 러한 워조의 효과는 수원국이 올바른 정책과 제도를 구축했을 때에만 나타나는 것이 아니라 이러한 수원국에서 는 그 원조의 효과가 더 컷을 뿐이며, 도든 수원국에서 다 같이 적 극적인 효과가 나타났다. 또 보건 등 인려투자가 잘 된 수원국에서 그 효과가 더 킸있다.
} 
〈표 2〉 파리선언의 12 가지 이행점검 지표 (2010년 달성목표)

\begin{tabular}{|c|c|}
\hline 5대 원칙 & 12 개 지표 \\
\hline 주인의식 & 1. 실행가능한 국가개발전략 \\
\hline \multirow{9}{*}{ 2. 수원국개발전략과 공 $\mathrm{O}=$ 국원조의 일관성 } & 2a. 신뢰할 공공재정 관리시스템 \\
\hline & 2b. 신로할 조달체체 \\
\hline & 3. 수원국 우선순위에 따른 원조 \\
\hline & 4. 능력개발할동 지원비중 \\
\hline & 5a. 수원국 재정관리체제 활용비중 \\
\hline & 5b. 수원국조달체제 할용비중 \\
\hline & 6. 원조집행기관 중복 방지 \\
\hline & 7. 원조의 예측가능성 강화 \\
\hline & 8. 원조의 국적 비연계섬 (untiedness) 강화 \\
\hline \multirow{3}{*}{ 3. 공여국간의 조화 } & 9. 공여국간 공동의 제도와 절차 \\
\hline & 10a 공동현지조사단 \\
\hline & 10b. 공동 국가정세 분석 \\
\hline 4. 섬과위주의 관리 & 11. 섬 과위주 체제 \\
\hline 5. 상호책임 & 12. 상호평 가책임의 부며 \\
\hline
\end{tabular}

※ 자듀: $\mathrm{OLCD}$

협의와 조정을 통하여 조화 있는 원조를 제공해아 한 다 (Harmonization), 넷째, 원조의 성과를 중요시하는 (Result-Driven) 원조정책을 추귀해야 한다. 다섯째, 수 원국과 공여국이 상호책임감(Mutual Accountability) 을 가지고 횝려함으로써 원조의 효과성을 제고하자는 것이다.

$\mathrm{OECD}$ 와 세계-은행(World Bank)의 첫 중간점검(2006 년) 결과는 틓ㅎ 세 가지 부문에서 진전이 부진하다고 지적하고 있다. 첫째, 국적 비연계성 원조의 비율이 아 직도 저조하고, 둘째, 공여국은 수원국의 재정관리 및 조달시스템을 아직도 충분히 할용하시 않고 있으며, 셋째, 공여국은 수원 궁에 설치한 현지사무소에 권한을
위임하는 것에 인색하다는 것이다.

\section{5. 국적 연계성 원조의 감소 (비연계성 원조의 확대)}

수원국은 원조자금으루 원조 공여국에서 생산된 물자 와 용역만을 구매해야 한다는 국적연계성 $(\mathrm{tied})$ 원조는 원조의 호과성을 낮추는 요인이라는 의미에서 이를 제 한하려는 움직임이 DAC 설립초기부터 꾸군히 지소하 여 왔었다. DAC의 연구에 의하면 국적연계성 원즈는 비언계성원조 보다도 $20 ~ 30 \%$ 의 원조자금을 낭비한 다. 1990 년대에 들어와서 원조의 효과성 제고가 중요 한 의제로 강조됨에 따라, $\mathrm{DAC}$ 회원 국은 1992년에 헬 
싱키 팩기지(Helsinki Padkage)라는 합의를 선언하게 되었다. 이에 의하면, 연계성 개발원조가 수출금융에 대한 보조금으로 할용되어서는 안 된다. 수출금융은 공개경쟁과 자유시장의 원칙에 따라야 하고, 연계성 개반원조는 시장조긴으로는 금응조단이 어려운 경우 (commercially non-viable)에 한하여 허용되어야 한 다. 따라서 세계은행으로부터 IDA조건(무이차; 30 40년 상환)으로 차관을 받을 수 없는 상위중소득국가 (Upper Middle Inoome Countries: UMTCs)에 대해서 는 국적 연계성 원조를 지원할 수 없고 순수한(100\%) 비 연계성원조반 제공해야하며, 개발프로젝트가 SDR 5천만 이상인 경우에는 국제공개경쟁입찰(ICB)을 통
해서 물자와 용역을 구매해야 한다는 원칙이 이 협약 의 주요 내용이다. 다만 개발프로젝트가 SDR 2백만 미만이거나 증여율(grant elements)이 $80 \%$ 를 초과하 는 경우와 최빈국에 대한 원조는 예외로 한다.

그러나 2002년 1월부터 발효한 최빈국에 대한 공적개 발원조 귄고안에서는 최빈국에 대해서도 국적 비연계 성(untied)원조만 제공할 수 있도목 하였다. 다만, 득 정 개발투자프로젝트와 무관한 독립된 기술협력원조 나 식량원조의 경우는 예외로 한다. 2006년에는 연계 성원조를 허용하년 소액원조의 상한선을 철폐하였고, 2008년에는 비연계성원조의 권고를 최빈국뿐만 아니

〈표 3〉 DAC 양자간 원조에서 국적 비연계성 원조의 추세

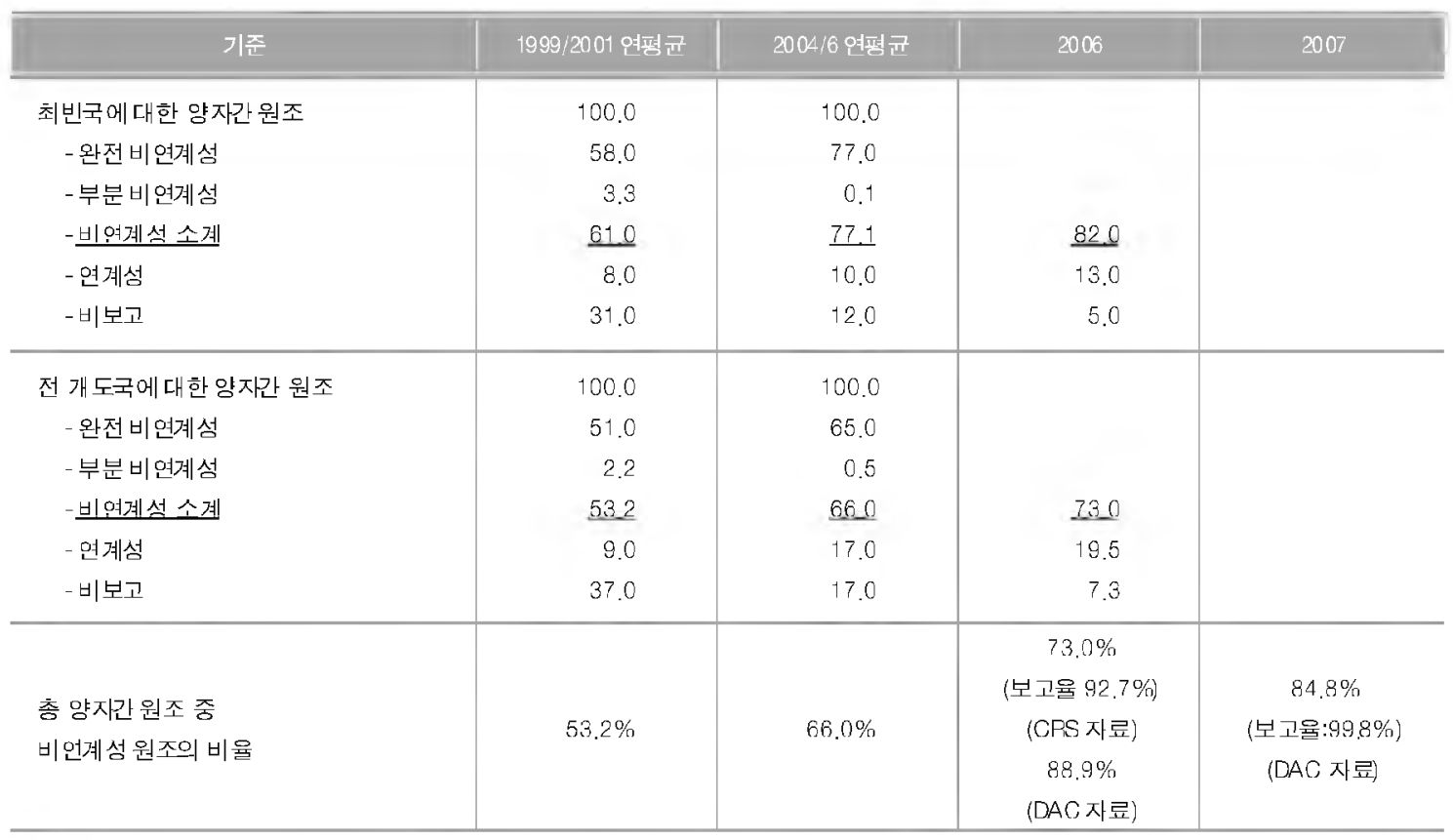

※ 주: 기술협녁원소 닟 원소행성비제외

: 자마: DAC(2008\%). Clay et al (2008) 
라 최대부채빈곤국(HIPC)에 대한 원조에도 획대하여 적용-하도록 합의하였다. 현재까지는 이러한 권고가 투 명하게 잘 지켜지고 있시는 않는 것 같으나, 점차 국적 비연계성원조의 영역이 더 확대되고 국적 연계성원조 는 축소되어가는 추세에 있음은 틀림없다. 자류의 제 약 때문에 일관된 지표가 없지만, $\mathrm{OECD}$ 의 $\mathrm{DAC}$ 원조 사료에 의하면, 2007 년에 $85 \%$ 의 양사간 DAC원조가 비연계성원조였다. 그러나 최근 $\mathrm{OECD}$ 의 creditor reporting system 자료에 의하면, 2006년에 양자간 $\mathrm{DAC}$ 원조의 $73 \%$ 가 비연계성원조였다. 이것은 1999/2001년 간의 비연계성원조 평균인 $53 \%$ 와 비교 된다. 뿐만 아니라 비연계성원조의 비율이 늘어난다고 해서 양자간 원조나 총원조가 줄어든다는 증거도 없 다. 오히려 양자간 원조에서 비언계성원조의 비율이 높은 국가에서 최벤국에게 제공하는 원조의 비중이 더 늘어난다는 증거는 있다 (Clay et al2008).

\section{6. 무상원조의 증가}

1990년붙터 다사간 국제원조기구의 유상원조(차관)는 증가추세이지만 무상원조는 징체되거나 감소하는 추 세이다. 이에 빈하여, 양자간 원조에서는 차관은 급격 히 줄어들고, 무상원조가 현저히 늘어가는 추세이다. 양사간의 무상원조가 증가하는 것은 중앙 및 동비 유럽 에 위치한 구 소련 연방국가에 내한 무상원조가 증가 한 것과 아프리카 등에 위치한 최빈국에 대한 부채탕 감이 증가한 것에 기인한다.

다자 원조기구의 원조에서 차관의 비중이 늘어가지만, 이러한 추세는 양자간 무상원조의 증가규모를 능가하
지 못하고 있다. 더욱이 양자간 유상원조도 급격히 감 소해왔다. 2001 2003년 사이에 공적 유상원조는 $\$ 52$ 십억 줄어들었시만 공적 무상원조는 $\$ 20$ 십억 증가하 였다. 따라서 공적원조의 순 총액은 $\$ 32$ 십익만큼 줄어 들었다.

공적개발원조의 총 순액에서 양사간 무상원조와 유상 원조가 차지하는 비율의 추세를 보면 1990 년에 양자 간 무상원즈는 $63 \%$ 를 차지하였으나 2002 년에는 $69 \%$ 로 증가하였고 2005년에는 80\%로 그리고 2006년에 는 76\%로 중가하었다. 이에 반하여 양사간 유상원조 는 1990 년의 $11 \%$ 에서 2002 년에는 $1 \%$ 로 줄어들었고 2005년과 2006년에는 $-3 \%$ 로 줄어 들었다. 국제기구 에 대한 출연금도 사실상 무상원조에 해당하지만, 전 체 ODA의 $30 \%$ 내외에서 안정적인 수준을 계속 유지 하고 있다.

1990 년 이후 무상원조의 비율을 증가해온 DAC 회원 국은 2005 2006년에 걸쳐서 평균 양자간 원조의 $86 \%$ 를 무상으로 제공했으며, 전체 $\mathrm{ODA}$ 의 $89 \%$ 를 무 상으로 제공했다. 이 비율은 2007 년에도 대동소이하 다. 양자간 원조 중 각 국별 유-무상원조의 비율을 보 면 대부분의 DAC회원국들이 양자간 원조의 $90 \%$ 이상 을 무상으로 제공하고 있으나, 소수의 회원국들은 아 직도 낮은 비율의 무상원조를 제공하고 있다. 내표적 인 국가가 일본-으로서 무상원조가 $41 \%$ 의 낮은 수준을 차지하고 있으며, 이태리의 경우에도 무상원조가 $67 \%$ 이며, 독일도 $76 \%$, 프랑스 $79 \%$, 스페인은 $84 \%$ 의 수준 을 유지하고 있다. 
〈그림 2) 다자간 및 양자간 유-무상원조 자금의 흐름

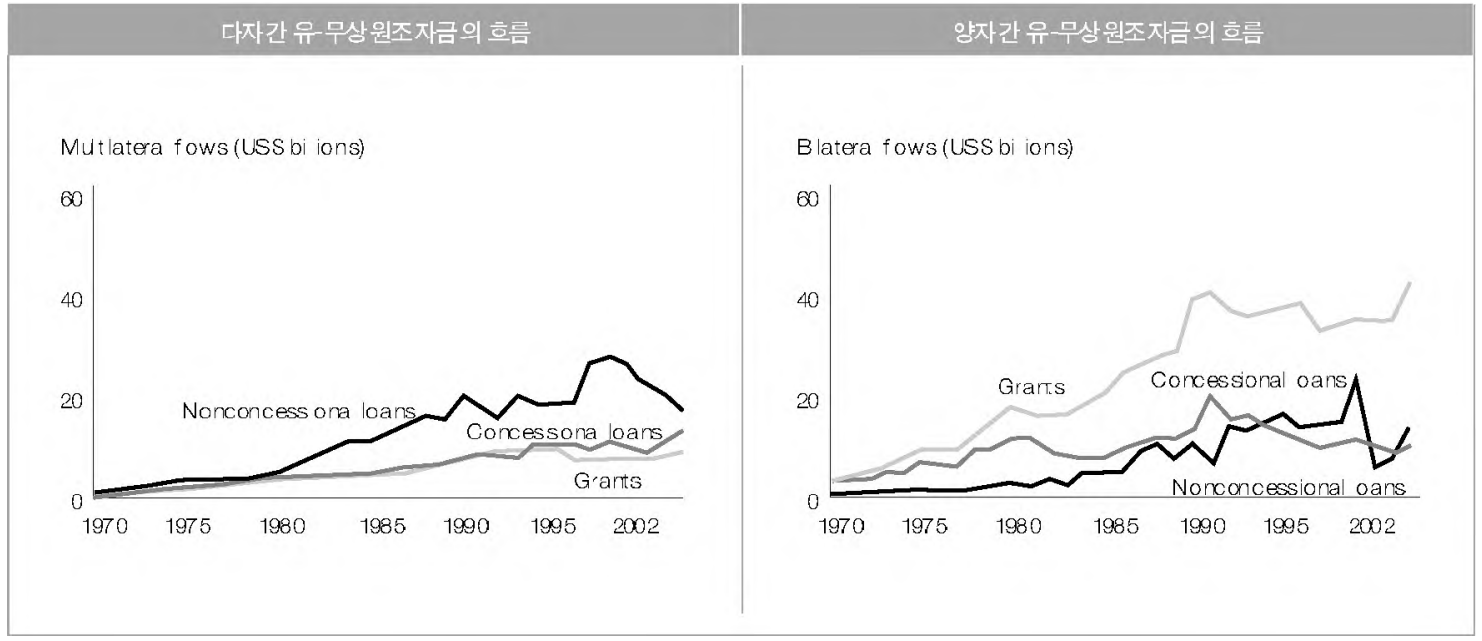

* 자료: World Pank

〈표 4〉 공적개발원조액 의 증감 (2001-2003)

\begin{tabular}{l|c}
\hline 순 공적 무상원조 (증여)(Net Official Grants) & +\$20B \\
\hline 순 공적 유싱원조 (차관) (Net Official Lending) & $-\$ 52 \mathrm{~B}$ \\
\hline 순 공적 원조 총계 (Net Official Flows) & $-\$ 32 \mathrm{~B}$ \\
\hline
\end{tabular}

* 자료: World Pank, Gilobal Development, Finance

〈표 5) DAC 공적 무상원조의 상대적 증가 추세 (1990-2006)

\begin{tabular}{c|c|c|c|c|c|c|c}
\hline \hline & $\begin{array}{c}1990-1991 \\
\text { 평균 }\end{array}$ & $\begin{array}{c}1995-1996 \\
\text { 평균 }\end{array}$ & 2002 & 2003 & 2004 & 2005 & 2006 \\
\hline $\begin{array}{c}\text { 공적개발원조의 } \\
\text { 총순액 (\$캑만) }\end{array}$ & $\begin{array}{c}(51,571) \\
100\end{array}$ & $\begin{array}{c}(57.277) \\
100\end{array}$ & $\begin{array}{c}(58,297) \\
00\end{array}$ & $\begin{array}{c}(69,065) \\
100\end{array}$ & $\begin{array}{c}(79,132) \\
100\end{array}$ & $\begin{array}{c}(107,099) \\
100\end{array}$ & $\begin{array}{c}(001,121) \\
-00\end{array}$ \\
\hline 양자간 무상원조 (증여) & 63 & 63 & 69 & 75 & 72 & 80 & 76 \\
\hline 2. 양자간 유상원조 (차관) & 11 & 6 & 1 & -2 & -4 & -3 & -3 \\
\hline 3. 국제기구에 대한 출연원조 & 26 & 31 & 30 & 27 & 32 & 23 & 27 \\
\hline
\end{tabular}

※ 자료: DAC (2007) 


\section{7. 사적 무상공여의 증가}

최근에 들어서 수원국 정부는 공적부채의 비중을 상내 적으로 높이고 빈면 사적 부채의 비중을 상대적으루 감소해 왔다. 그리나 이것은 대 기도국 사적 자금의 흐름이 간소했다는 것을 의미하시는 않는다. 오히려 사적 자본의 흐름은 부채(차관 또는 융자)를 제외하고 는 급격히 증가하는 추세에 있다. 틓ㅎ 유가증권투자 와 직접투자액은 급격히 증가하였다.

그 밖에비영러성 자본의 흐름이 크게 증가하였다. 득 히 $\mathrm{NGO}$ 가 제공하는 무상공여(grants)가 증가하였
고, 근로자의 본국 송금은 공적원조자금이나 사적윰 자자금의 규모를 능가하고 있다. 1990년에서 2003년 사이에 공적원조사금이 \$15십억 상당(빛채탕감을 제 외하면 $\$ 10$ 십익) 증가한데 비하여, $\mathrm{NGO}$ 의 무상공여 금은 $\$ 5$ 십억 상당 증가하였다. 근로자의 본국송금은 약 $\$ 80$ 십억 상당이나 증가하였다. 사적 무상공여자 금은 \$11십억에 이르렀다 (Roodman and Standley 2006).

공적 게발원조자금과 사적자금은 상호보완관계에 있는 것 같다. 1990 년에 공적개발원조자금은 대 개도국 자 본이동의 흐름 중에서 $64 \%$ 를 차지하였고 사적지금은

\begin{tabular}{|c|c|c|c|c|c|c|c|}
\hline 달러 & $\begin{array}{c}1990- \\
1991 \text { 평균 }\end{array}$ & $\begin{array}{c}1995- \\
1996 \text { 평균 }\end{array}$ & 2003 & 2004 & 2005 & 2006 & 2007 \\
\hline I. 공적개발원조 & $\begin{array}{c}(54,574) \\
6.1\end{array}$ & $\begin{array}{c}(57,277) \\
32\end{array}$ & $\begin{array}{c}(69,065) \\
55\end{array}$ & $\begin{array}{c}(79,432) \\
50\end{array}$ & $\begin{array}{c}(107,099) \\
35\end{array}$ & $\begin{array}{c}(104,370) \\
31\end{array}$ & $\begin{array}{c}\left(103,49^{-}\right) \\
23\end{array}$ \\
\hline II. 기타 공적자금 흐름 & $\begin{array}{c}(7,890) \\
9\end{array}$ & $\begin{array}{c}(7,861) \\
4\end{array}$ & $\begin{array}{c}(-3 / 8) \\
-0\end{array}$ & $\begin{array}{c}\left(-5,60^{-}\right) \\
-3\end{array}$ & $\begin{array}{c}(1,130) \\
0\end{array}$ & $\begin{array}{c}(-10,728) \\
-3\end{array}$ & $\begin{array}{c}(-6,138) \\
-1\end{array}$ \\
\hline $\begin{array}{c}\text { III. 사적자금의 흐름 } \\
\text { (시징가격) }\end{array}$ & $\begin{array}{c}(17,792) \\
21\end{array}$ & $\begin{array}{c}(108.610) \\
60\end{array}$ & $\begin{array}{c}(46,573) \\
37\end{array}$ & $\begin{array}{c}(75,262) \\
47\end{array}$ & $\begin{array}{c}(179,559) \\
59\end{array}$ & $\begin{array}{c}(194,762) \\
64\end{array}$ & $\begin{array}{c}(325,350) \\
74\end{array}$ \\
\hline 1. 직접투자 & 29 & 31 & 39 & 48 & 33 & 43 & 43 \\
\hline 2. 양자간 증권. 기타 & -9 & 28 & -1 & 3 & 29 & 21 & 31 \\
\hline 3. 다자간 사적자금 & 2 & -0 & 1 & -3 & 0 & * & -2 \\
\hline 4. 수촐금융 & -1 & 2 & & & & & \\
\hline 5. 부채탐감 & & & -2 & -0.5 & -3 & -3 & -0.6 \\
\hline $\begin{array}{l}\text { IV, 사적 } \\
\text { 무상원조 (증여) }\end{array}$ & $\begin{array}{c}(5240) \\
6\end{array}$ & $\begin{array}{c}(5871) \\
3\end{array}$ & $\begin{array}{c}(10239) \\
8\end{array}$ & $\begin{array}{c}(11320) \\
7\end{array}$ & $\begin{array}{c}(14712) \\
5\end{array}$ & $\begin{array}{c}(14648) \\
5\end{array}$ & $\begin{array}{c}(18508) \\
1\end{array}$ \\
\hline $\begin{array}{c}\text { 촣계 } \\
\text { (순지금 흐듬) }\end{array}$ & 100 & 100 & 100 & -00 & 100 & 100 & 100 \\
\hline
\end{tabular}

※ ( ) : 백막담러 자료: DAC (2007. 2008) 
〈표 7〉 근로자 송금의 규모

\begin{tabular}{c|c|c|c|c}
\hline & 1990 & 1995 & 2000 & 2004 \\
\hline \hline 중상위 소득 국가 (upper middle income) & 5.7 & 8.6 & 13.1 & 26.8 \\
\hline 중하위 소득국가 (lower middle income) & 17.5 & 34.8 & 41.9 & 55.6 \\
\hline 저소득 국가low income) & 8.1 & 13.3 & 21.7 & 43.4 \\
\hline 촣 계 & 31.3 & 56.7 & 76.8 & -25.8 \\
\hline
\end{tabular}

※ 자료: Worl d Bank (2005) Global Developm ent Finance

21\%에 그쳤지만, 2006년에는 그 비중이 징반대로 바 뀌었다. 즉 공적자금은 $34 \%$ 에 불과하나 사적자금의 대 개도국이동은 $64 \%$ 로 증가하였다. 이에 반하여, 공 적개발원조자금과 시민단체의 원조자금은 상호강화작 용을 하고 있다. 공적원조자금이 상대적으로 증대된 역할을 한 2000년대 초에 시민단체의 원조자금도 같 이 증가해 왔으나, 최는에 들어서 공적원조자금의 비 중이 상대적으로 줄어들게 되사, 시민난체의 원조사금 도 상대적으로 줄어들고 있다.

\section{8. 빈곤국과 중소득국 간의 원조의 균형은 불변}

원조 득히 무상원조의 비중이 빈곤국과 중진국 사이에 서 변하지 않고 있는 추세이다. 다만 중상위국에서 중 하위국으로 원조의 중심이 이전해가고 있다. 이리한 추세는 구 소련연방의 붕괴 후에, 동구권 국가에 무상 원조가 많이 제공되었기 때문이나, 차관이 중진국에 많이 제공된 것도 그 이유 중의 하나이다. 이것은 신진 공여국 원조의 초점이 빈곤퇴치라는 표면상의 인도주 의적 공적원조 목적에서 벗어나서, 실제로는 각국의 경제적, 정치적, 안보적, 문화적 목적에 중점을 두고
있음을 간접적으로 나타내고 있는 것으로 보인다.

특히, 무상원조는 중소득 국가보다는 소득수준이 낮고 부채(유상원조)의 상환부담을 감당하기 어려운 최빈구 과 기타 저소득국가에 더 많이 제공되어야 논리적이며 인도주의적 목적에도 맞다. 그러나 1970년이래 무상 원조는 점차 중소득 국가에 더 많이 배정되고 저소득 국가에 배분되는 비율은 1990 년이래 줄어들어 왔다. 다만 위로가 되는 것은 유상원조가 저소득국가보다도 중진국에 더 많이 배정되는 추세이다.

일반적으로 선진국들이 개도국에 원조를 배분할 때에 개도국의 소득수준과 정부-의 업무수행성적 특히 정책 과 제도의 우수성을 기준으로 하여 원조를 배분하는가 에 관하여는 학지들 사이에 의견이 대립되어 있다. 2007년 DAC의 자료에 의하면 소득수준과 정부의 업 무수행성적에 따라서 배분된 원조는 극히 적은 분량에 불과하고, 또 이러한 기준에 따른 원조가 전체원조에 서 차지하는 비율도 크게 변하지 않고 있다.

Easterly(2007)와 Easterly and Pfutze(2008)의 경제 통계학적 연구에 의하면, 선진국들의 원조는 개도국의 
필요성(소득수준)과 정책 및 제도의 우수성과 상관없 이 배분되며, 최는에 들어와서도 이러한 행태에는 변 화가 없다고한다.

그러나 다른 일련의 경제통계흭적 연구에 의하면 2000 년대에 들어와서 선진국은 개도국의 필요성과 정 책 및 제도의 앗수성에 점차 더 무게를 두고 수원국을 선정하는 행태를 보이고 있으녀, 또 사하라 이남의 아 프리카에도 타 지역보다 더 많은 원조를 제공하고 있 다고 한다. 다만 이러한 추세는 2004년 이후 더 미약
해 지고 있다고 보고한다 (Dollar and I evin 2004, Claessens, Cassimon and Van Campenhour 2007, World Bank 2008).

원조의 배분에서 개도국의 필요성 즉, 소득수준이 중 요한 기준으로 작용-함에 따라서 원조의 지역별 배분에 서도 사하라 이남의 국가와 중동-북아프리카의 국가 에 대한 원조가 증가하였다. 반면에 중앙아시아 지여 은 정체되었으며, 기타 아시아와 오세아니아, 중남미 및 유럽지역의 국가들은 감소하였다.

\begin{tabular}{|c|c|c|c|}
\hline 연 도 & $\begin{array}{c}\text { 저소득국가 } \\
\text { (최저 및 기타 저소득) }\end{array}$ & 중하위 소득 국가 & 중상위 소득 극가 \\
\hline 1971 & 57 & 26 & 17 \\
\hline 1981 & 55 & 19 & 25 \\
\hline 1990 & 71 & 21 & 8 \\
\hline 2000 & 62 & 34 & 4 \\
\hline $2006 / 7$ & 63 & 32 & 5 \\
\hline
\end{tabular}

※자다: 1$) A C(200 \%, 2008)$

〈표 9〉 공적 개발원조의 빈곤국에 대한 비중

\begin{tabular}{|c|c|c|}
\hline & 빈곤 개도국 & 개도국 전체 \\
\hline 무상공여 (Grants) & $\begin{array}{l}1970 s: 70 \% \\
1990 s: 50 \%\end{array}$ & $\begin{array}{l}100 \% \\
100 \%\end{array}$ \\
\hline 유상원조 (Non-Concessional loans) & $\begin{array}{l}19808: 29 \% \\
1990 s: 21 \%\end{array}$ & $\begin{array}{l}100 \% \\
100 \%\end{array}$ \\
\hline 수원국의 GDP 대비 공적원조 & $\begin{array}{l}-990: 3.7 \% \\
2003: 2.0 \%\end{array}$ & $\begin{array}{l}1980: 2 \% \\
2003: 1 \%\end{array}$ \\
\hline
\end{tabular}

※ World Bank, Global Development Finance 


\begin{tabular}{|c|c|c|}
\hline & 2002 & 2006 \\
\hline $\begin{array}{c}\text { 세계은행 IDA의 원조배분원칙 } \\
\text { (빈곤수준과 정부업무수항 성적)에 } \\
\text { 따른 DAC 임자원조의 바분 }\end{array}$ & $19 \%$ & $17 \%$ \\
\hline
\end{tabular}

※ 자료: DAC (2007)

〈표 11〉 국제공적개발원조의 지역별 배분

\begin{tabular}{c|c|c|c|c}
\hline 지역 & $1995 / 96$ & $2000 / 01$ & $2005 / 06$ & $2006 / 7$ \\
\hline \hline 사하라이남 아프리카 & 33.9 & 33.4 & 42.8 & $48 .^{-}$ \\
\hline 중동 및 북아프리카 & 12.0 & 11.2 & 17.5 & 14.0 \\
\hline 중앙-남이시아 & 11.6 & 12.6 & 10.0 & 12.6 \\
\hline 기타 아시아 및 오세아니아 & 15.4 & 10.5 & 6.6 & 10.8 \\
\hline 중남미 & 12.6 & 12.8 & 7.1 & 10.3 \\
\hline 유럽 & 5.3 & 10.9 & 6.3 & 1. \\
\hline 전체 & 100.0 & 100.0 & 100.0 & -00.0 \\
\hline
\end{tabular}

※ 자료: DAC (2007)

\section{9. 부채탕감 원조와 사회}

\section{- 행정 인프라 및 무역에 대한 원조 증가}

양자간 원조의 수단별 배분을 보면 무상원조가 유상원 조에 비하여 급격히 증가하였다는 것은 이미 보았다. 앙자간 무상원조에서 급격히 증가한 수단은 부채탕감 이다. 따라서 개발투자원조와 기술원조 및 식량원조는 상대적으로 감소해왔다. 개발투자원조는 1995 96년 에 $30 \%$ 수준에 달하던 것이 2005 년과 2006년에는 $14 \%$ 수준으로 하락하였다가 2007년에 들어서야 겨웅 $26 \%$ 수준을 회보했다. Kharas는 양자간 원조의 대부
분이 공여국의 특정한 목적이라는 꼬리표가 붙어 있어 서, 개도국이 자신들의 개발계획에 기반하여 투자 프 루그램을 민들어시 사용할 수 있는 원조는 전체원조 의 $40 \%$ 도 채 되지 않는다고 계산했다. 아프리카에 대 한 원조의 경우에도 수원국이 투사 프로기램을 만들 수 있는 원조는 전체원조의 $12 \%$ 에 지나지 않으녀, 이 수준은 지난 몇 년간 조금도 증가하지 읺았다고 계산 했다 (Kharas 2007), 공적 게발원조가 게도국의 경제 성장에 미치는 영향에 관하여 학자들 사이에 의견이 나누어져있고 경험적 연구도 상반되는 걸과를 보여주 는 것은 이러한 개빌투자에 대한 원조의 배분이 낮은 
수준에 머물러 있는데 그 중요한 원인이 있다고 생각 된다.

원조 분야별 배분을 보면, 최근에 와서 사회(교육 보건 등)-행정 인프라 분야가 급증하였고, 빈면에 경제 인
프라와 공업-농업, 그리고 물자 및 프로그램 등 생산 분야에 직접적으로 영향을 미치는 분야에 대한 원조는 급감하었다. 이너한 변화는 원조의 효과가 수원국의 주인의식과 수원국의 정책 및 제도의 우수성에 크게 좌우된다는 주장과 연구견과에 기인한다고 할 수 있

〈표 12〉 국제공적개발원조의 수단별 배분

\begin{tabular}{|c|c|c|c|c|c|c|c|c|}
\hline & $\begin{array}{c}\text { 1990-1991 } \\
\text { 평균 }\end{array}$ & $\mid \begin{array}{c}1995-1996 \text { 평 } \\
\text { 균 }\end{array}$ & 2002 & 2008 & 2004 & 2005 & 2006 & 2007 \\
\hline 공적개 발원조 (순 자금흐름) & 100 & 100 & 100 & 100 & 100 & 100 & 100 & 100 \\
\hline 1. 양자간 무상원조 (증여) & 63 & 63 & 69 & 75 & 72 & 80 & 76 & 72 \\
\hline - 기술원소 & 35 & 4 & 38 & 34 & 33 & 25 & 27 & 14 \\
\hline -개발식량원조 & 5 & 5 & 2 & 2 & 3 & 0 & 0 & - \\
\hline -인도주의적 원조 & 5 & 5 & 7 & 7 & 8 & 7 & 8 & 8 \\
\hline -채무탕감 & 15 & -0 & -1 & 17 & 11 & 29 & 23 & 10 \\
\hline -햄점비 & 5 & -0 & 47 & 7 & 8 & 4 & 4 & 4 \\
\hline 2. 먕자간 유상원조 (차 관) & 11 & 6 & 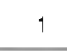 & -2 & -4 & -3 & -3 & -2 \\
\hline 3. 국제기구에 대한 출연금 & 26 & 31 & 30 & 27 & 32 & 23 & 27 & 30 \\
\hline
\end{tabular}

x 자료: DNC (2007. 2008)

〈표 13〉 국제공적개발원조의 분야별 배분

\begin{tabular}{|c|c|c|c|}
\hline 분 야 & $1985 / 6$ & $2005 / 6$ & 2007 \\
\hline 사회-행정 인프라 & 25 & 32 & 37 \\
\hline 경제 인프라 & 17 & 11 & -2 \\
\hline 농업 & 12 & 3 & 4 \\
\hline 공업및 기타 생산 & 7 & 2 & 2 \\
\hline 물자 및 프로그램 원조 & 22 & 3 & 1 \\
\hline 인도주의적 지원 & 2 & 8 & 7 \\
\hline 기타 & 14 & 41 & 35 \\
\hline -(NGO에 대한 지원 또는 $N G O$ 를 통한 지원) & $(-)$ & (5) & (6) \\
\hline -(무역확대를 위한 원조) & $(-)$ & (24) & (NA) \\
\hline 총 계 & -00 & 100 & 100 \\
\hline
\end{tabular}

\# 자료: DAC (2007. 2008) 
다. 또 원조 분야가 다양해져서 전통적인 원조 분야에 속하지 않는 원조, 예를 들면 인간안보 또는 내분 중식 과 재건설을 위한 원조나 무역의 사유화와 확대를 위 한 원조가 증가하였다. 트히 무역의 확대를 위한 원조 는 $2005 / 6$ 년에 전체 원조 의 $24 \%$ 를 차지 할 민큼 증가 되었다. 원조가 아니라 무역을 퉁하여 개도국의 경제 사회 발전을 기하는 것이 더욱 효율적이라는 국제기구 의 노럭이 반영된 것이라고 하겠다 (Lee 2008 , Njinkeu and Cameron 2008).

\section{0. 원조시장의 치열한 경쟁}

1945년부터 많은 수의 다자간 원조기구와 양자간 원 조기구가 새로이 설립되었고, 이렇게 생성된 원조기구 는 거의 하나도 폐기된 것이 없이 오늘날까지 상존하 고 있으녀, 오히려 방계기구를 신설하게 되었다. 오늘
날 국제원조기구만 해도 230 기에 달하며, 최근에는 22 개의 $\mathrm{DAC}$ 회원국 이외에, 중진국까지 국제개발협력 에 참여하기 위한 양사간 원조기구를 신설하여 할동하 고 있다(슬로베니아, 한국, 태국, 중국, 인도, 터키, 브 라질, 아르헨티나, 사우디아라비아 등 중동국가). 이러 한 신생 원조공여국의 원조는 2006 년에 이미 $\$ 8$ 십억 에 달하었다 (Kharas 2007). 사적 원조기관을 합하면 전 세계적으로 1,200 개가 넘는 원조기구가 존재한다 고 세계은행은 보고하고 있다. 그 결과 한 수원국 당 원조기관의 수가 계속 늘어니게 되고, 게별적인 원조 사업의 수는 늘어나면서 규모는 줄어들고, 수원국이 원조의 제공을 호율적으로 조정하지 못하게 되고, 원 조시장은 공급자 위주의 원조사업으로 치닫는 경향이 많아 원조의 호과성이 줄어들고, 원조기관 상호간에 치열한 경쟁을 낳게 되었다.

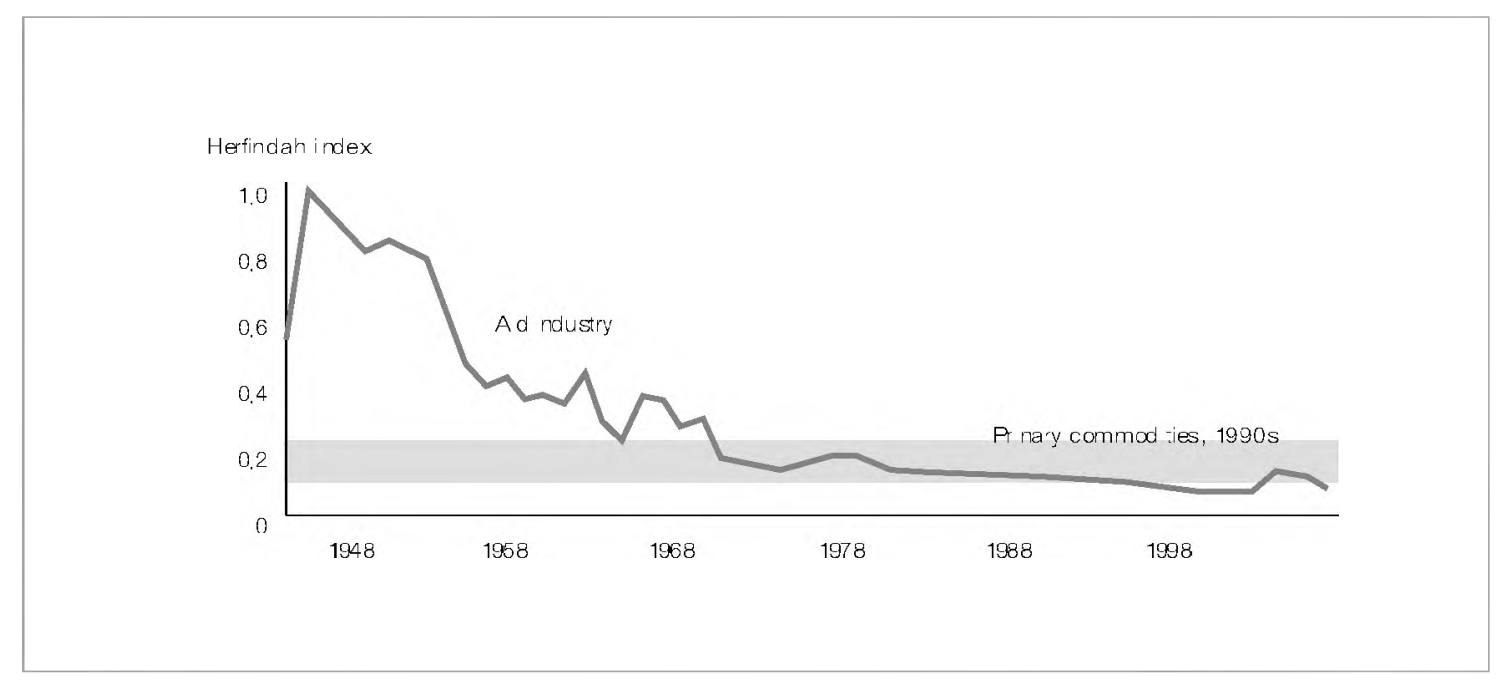

※ 자료: OECD Development Assis tance Comm ittee; Klein and Hardford 2005 Calculations: Ver leger 1993. 
오늘날의 원조시장은 왼전경쟁에 가끼운 상태이며 원 자재 시장보다도 더 경쟁적이다. 시장의 독점도를 측 정하는 한 방법으로 Herfindahl Index(HI)가 사용되 고 있는데 완전 독짐의 경우는 그 지표가 “1" 이고 완전 경쟁의 경우에는 "0"으로 대표된다. 이 지표를 이용하 면, 1950 년대의 원조시장은 $\mathrm{HI}$ 가 0.5 에 불과하였다. 그러나 최근에는 0.1 에 도달하었다.

그 견과, 지리적으로나 역사적으로 중점적 지원을 받 아오던 수원지역과 국가가 바뀌어지는 경우가 많다. 또 수원국 당 원조기관의 수가 늘어나서, 수원국의 행 정능럭에 부담을 주게 되어 수원행정의 질과 원조의 호과성이 하락하는 현상이 빚어져 왔다.

이러한 폐해를 최소화하기 위하여 원조기관 간의 협력 과 조화가 강조되고 수원국이 주인의식을 가지고 빈곤 퇴치와 개빌 정책을 수립하는 한편, 원조공여국은 이러 한 정책에 인치하는 원조 계획을 수립하는 것이 강조되 고 있다(파리 선언). 다른 한편으로는 각각의 원조공여 국은 원조시장에서 웅위를 점유하기 위하여 철서하게 경쟁원리를 도입하기도 한다. 예를 들면, 원조기관은 정책과 프로그램을 수립하고 원조자원을 배분하는 일 에 전념하고 집행은 산 - 학 - 연구기관 및 비정부 민 간단체(NGO) 등 외비기관에 위임(아웃소싱)하거나 이 들과 협럭하여 공동으로 집행하는 전략을 채택한다. 또 기존의 원조기관을 원조정책기구와 원조집행기구 로 분리하여 정책과 집행의 효율성을 제고하려고 한 다(예, 영국의 연방개발공사가 집행을 담당), 뜨는 식 량 쿠폰이나 건강진료 쿠폰과 같이 쿠폰(coupon) 또 는 바우처(voucher)를 빌행하여 배급함으로써 원조의
집행을 단순화하고 저렴하며 용이하게 하는 전락을 사용한다.

\section{IV. 맺음말}

국제개발협력의 변화와 최근의 주세를 통해서 한국 공 적개발원조의 선진화를 도모하는네 고훈과 시사전을 반견할 수 있다.

첫째, 한편으로는 인도주의에 기반을 다고 또 한편으 로는 냉전에 대비하는 정책수단으로서 시작한 국제개 빌협력은 국제징치, 경제, 문화 등 여건의 변화에 맞추 어서 그 목적과 정책의 번화를 기듭해 왔다. 한국의 원 조목적과 정칙도 변화하는 국제정세에 맞추어 신축성 있게 적응하고 조정 되어야 할 것이다.

둘째, 오늘난의 국제개발협력은 개도 국의 빈곤타파와 경제발전을 목적으로 하면서도 원조공여국의 정치적, 경제적, 문화적 목적을 충족시키 너는 녹합적인 요소를 지닌 징책수단이다. 따라서 수원국과 공여국은 협상과 타협을 거쳐시 상호교류와 호.헤의 목적을 단성하도록 노력해야한다.

셋째, 수원국과 공여국은 국제개발협럭이지닌 상호호 혜의 목적을 효율적으로 달성하기 위하여 공동으로 노 력해야 할 책임을 가진다. 수원국은 주인의식을 가지 고 개발과 빈긴타파전략을 수립해야 한다. 공여국은 자국의 목적과 수원국의 발전전략이 일치하도목 노럭 하고 수원국의 조징과 집행의 부담을 딜어주도록다른 
원조공여국과 협조해야한다. 또 가급적 원조가 국적에 연계되지 않고 쓰일 수 있도록 개방해야하며, 수원국 의 보채상환 비담을 경감하기 위하여 무상원조의 비중 을 증가시켜 나가야 한다.

넷째, 원조의 양적확대와 함께 원조의 개념이 확대되 어야 한다. 전통적인 사회간접사본의 확충 외에도 공 공제도와 정책 및 행정의 개선, 인러과 기술개발, 기 본적인 안보와 치인의 확보, 내전의 종식과 정치적 사회적 · 경제적 복구도 포함하는 포괄적인 원조가 되 어야한다.
다섯째, 원조의 배분도 공여국의 목적을 고려하여 수 원국을 선정하면서도 수원국의 필요성과 제도와 정책 의 아수성에 중점을 두고 수행되어야 한다, 기본적으 로 빈곤국에 무상원조의 배분을 증가하고 중 · 소득 국 가의 인프라확충에 유상원조의 배분을 집중해야 한다. 원조의 부문과 수단도 한국의 비교우위를 고려하여 선 택해야 하며, 효율적인 원조로 치열한 원조경쟁에서 듬새시장을 확보하여야 한다. 효율적인 원조를 위하여 시는 다양한 이해관계자를 포섭하여 연계망을 마련하 고 분업과 헙력을 추구해 나가야 한다. 


\section{[ 참고 문헌 ]}

1. 국너문헌

이계우. 박지훈 (2007) 한국의 공적개발원조 20년의 평가, 한국개발연구, 29권 2호: 43-74

2. 외국문헌

Burnside, Craig and David Dollar (2000) Aid, Policies, and Growth, American Eœonomic Review, Vol. 90, Sept : 847-68

Dollar, David, and Victoria Levin (2004) Increasing Selectivity of Foreign Aid: 1980-2002, Policy Working Paper 3299. World Bank Washington, DC.

Classens, Stijn, Danny Cassimon, and Biom Van Campenhour (2007) Empirical Evidenœe of the New International Aid Architecture, IMF Working Paper WP/07/277, IMF, Washington. DC.

Clay, Edward J., Matthew Geddes, Luisa Natali, and Dirk Wilem te Velde (2008) Thematic Study, The Development Effectiveness of Untied Aid: Evaluation of the Implementation of the Paris Dedaration and of the 2001 DAC Recommendation on Untying ODA to the LDCs, Phase 1 Report Ministry of Foreign Affairs, Printing Office, Copenhagen.

Clements, Michael, Steven Radelet, and Rikhil Bhavnani (2004) Counting Chickens When They Hatch: the Short-Term Effect of Aid on Growth, Center for Global Development Working Paper M4. Washington, DC.

DAC (2008) Development Cooperation Review (mww.oecd.org)

DAC (2007) Development Cooperation Review (www.oecdorg)

Inada, Junichi (2005) Japan's Emerging Role in Peace-building and Post-Conflict Reconstrudion: Have Traditional Norms Changed?, in Japanese ODA at 50: An Assessmenl, Asia Program Special Report No. 128: 13-16. Woodrow Wilson International Center for Scholars. Washington, DC. 
$\mid$

Isham, Jonathan, Daniel Kaufmann, and Lant Pritchett (1995) Governanœe and Retums on Investment: An Empirical Investigation, World Bank PolicyResearch Working Paper 1550. Washington DC.

Kazuo Sunaga (2004) The Reshaping of Japan's Official Development Assistanœe (ODA) Charter, Disaussion Paper on Development Assistance No. 3, FASID, Tokyo.

Kharas, Homi (2007) Trends and Issues in Development Aid Wolfensohn Center for Development Working Paper, Brookings Institute, Washington, DC.

Klein. Michael and Tim Harford (2005) The Market for Aid. Intemational Finance Corporation, Washington, DC.

Lee, Kye Woo (2008) Development Cooperation for Economic Integration in East and South Asia CNAEC Research Series, Korea Institute for International Economic Policy, Seoul.

Le, Kye Woo (2002) International Organizations: The World Bank, in Yoo, Jang Hee and Kye Woo Lee (eds.) Introduction to Intemational Studies, Ewha Womans University Press, Seoul.

Njinkeu, Dominique and Hugo Cameron (eds.)(2008) Aid for Trade and Development, ILEAP and JEICP, Cambridge University Press, New York.

OECD/DAC (2007) 2006 Development Cooperation Report Vol. 8, No. 1, Paris.

Padelet, Steven (2003) Challenging Foreign Aid: A Policymaker's Guide to the

Millennium Challenge Account, Center for Global Development, Washington DC.

Pajan Raghuram and Arvind Subramanian (2005) Aid and Growth: What does the CrossCountry Evidence Really Show? IMF Working Paper 05/127. Washington DC.

Poodman, David and Scott Standley (2006) Tax Policies to Promote Private Charitable Giving in DAC Countries, Center for Global Development Working Paper 82, Washington, DC World Bank (2008) Global Development Finance, Washington, DC. 